\title{
CRITICAL CASES IN \\ ORGANISATIONAL BEHAVIOUR
}




\title{
MANAGEMENT, WORK AND ORGANISATIONS
}

\author{
Series editors: Gibson Burrell, Warwick Business School \\ Mick Marchington, Manchester School of Management, \\ UMIST \\ Paul Thompson, Department of Business Studies, University \\ of Edinburgh
}

This series of new textbooks covers the areas of human resource management, employee relations, organisational behaviour and related business and management fields. Each text has been specially commissioned to be written by leading experts in a clear and accessible way. An important feature of the series is the international orientation. The titles will contain serious and challenging material, be analytical rather than prescriptive and be particularly suitable for use by students with no prior specialist knowledge.

The series will be relevant for a number of business and management courses, including MBA and post-experience courses, specialist masters and postgraduate diplomas, professional courses and final-year undergraduate and related courses. The books will become essential reading at business and management schools world wide.

\section{Published:}

Paul Blyton and Peter Turnbull The Dynamics of Employee Relations Martin Corbett Critical Cases in Organisational Behaviour

Karen Legge Human Resource Management

Harry Scarbrough The Management of Expertise

\section{Forthcoming:}

Sue Ledwith and Fiona Colgan Women in Organisations

Helen Newell and John Purcell Business Strategy and the Management of Human Resources

Helen Rainbird Training in the Workplace

Harvie Ramsey Involvement at Work

Michael Rowlinson Organisations and Institutions

Adrian Wilkinson, Mick Marchington, Tom Redman and Ed Snape

Total Quality Management

\footnotetext{
Series Standing Order

If you would like to receive future titles in this series as they are published. you can make use of our standing order facility. To place a standing order please contact your bookseller or. in case of difficulty write to us at the address below with your name and address and the name of the series. Please state with which title you wish to begin your standing order. (If you live outside the United Kingdom we may not have the rights for your area. in which case we will forward your order to the publisher concerned.)
}

Customer Serviees Department. Macmillan Distribution Lid Houndmills. Basingstoke. Hampshire RG21 6XS. England 


\section{CRITICAL CASES IN ORGANISATIONAL BEHAVIOUR}

\section{J. Martin Corbett}




\section{(C) J. Martin Corbett 1994}

All rights reserved. No reproduction, copy or transmission of this publication may be made without written permission.

No paragraph of this publication may be reproduced, copied or transmitted save with written permission or in accordance with the provisions of the Copyright, Designs and Patents Act 1988, or under the terms of any licence permitting limited copying issued by the Copyright Licensing Agency, 90 Tottenham Court Road, London W1P 9HE.

Any person who does any unauthorised act in relation to this publication may be liable to criminal prosecution and civil claims for damages.

First published 1994 by

THE MACMILLAN PRESS LTD

Houndmills, Basingstoke, Hampshire RG21 2XS

and London

Companies and representatives

throughout the world

ISBN 978-0-333-57751-6

ISBN 978-1-349-23295-6 (eBook)

DOI 10.1007/978-1-349-23295-6

A catalogue record for this book is available from the British Library.

$\begin{array}{llllllll}10 & 9 & 8 & 7 & 6 & 5 & 4 & 3\end{array}$

$\begin{array}{llllllll}03 & 02 & 01 & 00 & 99 & 98 & 97 & 96\end{array}$ 
To Angie, my wife and best friend 


\section{Contents}

List of figures and tables

1 Case study analysis of organisational behaviour

Critical cases in organisational behaviour

Critical issues in organisational behaviour

Characteristics of the cases

The structure of the book

How to use the book

\section{PART 1 ANALYSING INDIVIDUAL BEHAVIOUR IN ORGANISATIONS}

2 The meaning of work, motivation and commitment 9

Introduction 9

Case 1: The lottery question $\quad 11$

Case 2: Employee commitment: on becoming a torturer 13

Case 3: The job enrichment experiment 17

Case 4: Smart pills for management ills? 23

Case 5: B.F. Goodrich Wheel and Brake Company 26

Case 6: Commitment as dissent $\quad 31$

Case 7: Irresponsible autonomy in the factory 32

3 The management of meaning, motivation and commitment 37

Introduction $\quad 37$

Case 8: Selection and retention at Compservices Limited Neil Anderson $\quad 39$

Case 9: Recruiting helpline counsellors: dilemmas in validation Yasmin Frings and Neil Anderson $\quad 42$

Case 10: Job design at $\mathrm{HBO}$ computing $\quad 48$

Case 11: Increasing employee commitment at Stewart and Clegg Enterprises 
Case 12: Managing motivation at Technocraft

Case 13: Take your mother not your lover

Margaret Collinson and David Collinson

Case 14: Greenpeace International

\section{PART 2 ANALYSING GROUP BEHAVIOUR IN ORGANISATIONS}

4 Interpersonal relations and group decision-making 71

$\begin{array}{ll}\text { Introduction } & 71\end{array}$

Case 15: The rise and fall of the Chevrolet Corvair 73

Case 16: Death in the Ford Motor Company balance sheet 77

Case 17: Take it away, maestro! $\quad 80$

Case 18: Crisis Line Les Prince 83

Case 19: Obedience to authority 88

Case 20: Managing change at Byfield Business College 92

Case 21: Automate or liquidate 95

5 Leadership $\quad 100$

Introduction 100

Case 22: John De Lorean 102

Case 23: Military leadership and the fall of Singapore 105

Case 24: When leadership fails - the case of fragging 109

Case 25: And some have it thrust upon them: a case study of unwanted leadership Les Prince 112

Case 26: Centaur Office Supplies $\quad 120$

Case 27: The Mussolini of Detroit 123

Case 28: Conflict at Medical Supplies Limited 129

\section{PART 3 ANALYSING ORGANISATIONAL BEHAVIOUR}

6 Inter-group relations 135

Introduction $\quad 135$

Case 29: The launch of space shuttle flight 51-L 136

Case 30: 'PROMIS' and the politics of expertise 144

Case 31: Pluto Telecommunications 146

Case 32: Management of innovation at Business Database Company

Case 33: Managing change at Cox's Container Company 154

Case 34: Making the worker safe for the workplace 156

Case 35: At the cutting edge: is change necessary at Waterford Crystal? Brendan McSweeney 159

$\begin{array}{lll}7 & \text { Organisational design and change } & 178\end{array}$ Introduction $\quad 178$

Case 36: Redefining corporate strategy at IBM 179 
Case 37: Restructuring of medical physics departments Louise Fitzgerald

Case 38: Handy Snack (Distributing) Company

Case 39: Volorg: an international charity David C. Wilson 193

Case 40: Argus Home and Garden Design Limited

Case 41: The Simkin Café Chain

Case 42: Franchising corporate values at the Body Shop 203

8 Technology and organisation 207

Introduction $\quad 207$

Case 43: New technology and the Skolt Lapplanders 209

Case 44: Human-computer interface problems at North Staffordshire Royal Infirmary

Case 45: Egan and Doyle Publishing 211

Case 46: The Cyberpunk: villain or victim? 215

Case 47: The inter-disciplinary design of technology 219

Case 48: Technological change in the US Internal Revenue Service

Case 49: 'Living' with new technology: like pigs to the slaughter?

\section{PART 4 ANALYSING ORGANISATIONAL ENVIRONMENTS}

9 Organisation and environment 237

Introduction 237

Case 50: Hadley Industries and the UK cartel culture 238

Case 51: IBM and the management of market uncertainty 241

Case 52: The ethics of Church investment 249

Case 53: To boldly go from prisoners' dilemma to executive decision 248

Case 54: Employee commitment to the Nissan Motor Company 252

Case 55: Multi-national corporations and the circles of pesticide poisoning $\quad 255$

Case 56: A cross-cultural comparison of work values 258

$\begin{array}{ll}\text { Bibliography } & 261\end{array}$ 


\section{List of Figures and Tables}

Figures

3.1 The production process at $\mathrm{HBO}$

6.1 The correlation between temperature and O-ring incidents $\quad 138$

6.2 The NASA launch chain of command

7.1 Organisation structure of the UK National Health Service, 1990183

7.2 Medical physics department: St James' Hospital

7.3 Medical physics department: Church Hospital

8.1 Pigs to the slaughter?

9.1 The prisoners' dilemma

Tables

2.1 The lottery question

2.2 Means and results of statistical analyses for effects of job enrichment on drillers' psychological reactions

9.1 Total revenues and profits for IBM CPUs by memory size (1966 estimates in \$ millions)

9.2 Percentage distribution of income versus cost of IBM field personnel installing 360 systems (1967)

9.3 Rank ordering of work values for a sample of eight countries 260 


\section{Acknowledgements}

This book has benefited from the contributions, encouragement and advice of many people. I would especially like to thank Gibson Burrell, Mick Marchington and Paul Thompson for their support and encouragement; Judith Clegg for her brief yet highly productive research assistance; Keith Povey for his swift and helpful copy-editing; Stephen Rutt and Jane Powell at Macmillan for their forbearance; and Neil Anderson, Margaret and David Collinson, Louise Fitzgerald, Yasmin Frings, Les Prince, Brendan McSweeney, and Dave Wilson for their invaluable contributions to this collection of case studies.

In addition, I would like to express my thanks to Itzhak Harpaz and the British Psychological Society for permission to reproduce Table 2.1 on page 12, as well as to Howard Rosenbrock and Springer-Verlag Publishing for permission to reprint the debate featured in case 47, pages 219-28.

Finally, I should like to thank (and congratulate) the creator of the splendid cartoon reproduced, somewhat crudely, on page 232. Despite extensive inquiries I have been unable to ascertain the identity of the artist or the magazine in which the original cartoon was published. Should anyone be able to enlighten me on this matter could they please get in touch so that due acknowledgment can be made. 